\title{
Effect of Panchagavya foliar spray on the plant metabolism and grain yield of Tenai under rainfed condition
}

\author{
K. Ananthi* and P. Parasuraman ${ }^{1}$ \\ Department of Crop Physiology, Centre of Excellence in Millets, Athiyandal, Tiruvannamalai (T.N.) India \\ (Email: ananthiphd@yahoo.com)
}

\begin{abstract}
The crop growth and development are constantly influenced by environmental conditions such as stresses which are the most important yield reducing factors in the world. Millets cultivation is the most important agricultural operation in the country, not only in terms of food security, but also in creating better livelihoods, opportunities for rural population. Water stress and other abiotic stresses can dramatically limit and reduce the plant growth and productivity. In the frame of physiological window, mild drought induces regulation of water loss and uptake in plants allowing maintenance of their leaf relative water content within the limits where the photosynthetic capacity shows no or little changes. But severe drought induces unfavourable changes in plants, leading to inhibition of photosynthesis and growth. The use of bioregulators is the quickest and surest way of boosting crop production under rainfed condition. Panchagavya is an organic product blended from five different cow products, commonly applied to crop plants in organic farming. It is used as foliar spray, soil application and seed treatment. It can act as growth promoter and immunity booster. The organic Panchagavya foliar spray significantly influenced various physiological and biochemical parameters. A field experiment was conducted at Centre of Excellence in Millets, Athiyandal, Tiruvannamalai, during Kharif, 2017 to study the effect of Panchagavya foliar spray for enhancing the productivity of tenai under rainfed situation. In a water shortage conditions, application of enriched FYM +Recommended dose of fertilizer + 3\% Panchagavya foliar spray improves plant height, no. of tillers per plant, total dry matter partitioning, SPAD chlorophyll content and highest grain yield $\left(1739.0 \mathrm{~kg} \mathrm{ha}^{-1}\right)$ of tenai under rainfed condition.
\end{abstract}

Key Words : Bioregulators, Panchagavya, Plant height, No. of productive tillers, SPAD chlorophyll, TDMA, Yield

View Point Article : Ananthi, K. and Parasuraman, P. (2020). Effect of Panchagavya foliar spray on the plant metabolism and grain yield of Tenai under rainfed condition. Internat. J. agric. Sci., 16 (2) : 265-269, DOI:10.15740/HAS/IJAS/16.2/265-269. Copyright@ 2020: Hind Agri-Horticultural Society.

Article History : Received : 07.11.2019; Revised : 22.05.2020; Accepted : 26.05.2020

\footnotetext{
* Author for correspondence :

${ }^{1}$ Department of Agronomy, Centre of Excellence in Millets, Athiyandal, Tiruvannamalai (T.N.) India
} 